\title{
Antigen Unit per Milliliter
}

National Cancer Institute

\section{Source}

National Cancer Institute. Antigen Unit per Milliliter. NCI Thesaurus. Code C70500.

A measure of an antigen potency defined as a number of antigen units per one milliliter of product. 